\title{
Investigation of the Effect of GnRH (Deslorelin) on the Histochemical Structure of Salivary Glands in Rats
}

\author{
Investigación del Efecto de la GnRH (Deslorelina) sobre la \\ Estructura Histoquímica de las Glándulas Salivales en Ratas
}

Sema Uslu'; Gamze Çakmak² \& Mecit Yörük³

USLU, S.; ÇAKMAK, G. \& YÖRÜK, M. Investigation of the effect of GnRH (Deslorelin) on the histochemical structure of salivary glands in rats. Int. J. Morphol., 37(3):1008-1015, 2019.

SUMMARY: This study was planned to determine the histochemical alterations of the submandibular gland by implantation of long-term GnRH (deslorelin $4.7 \mathrm{mg}$ ). Eighteen Wistar albino rats were used in the study. Alcian blue (AB; pH: 2.5), periodic acid-Schiff (PAS) staining was performed to determine the microscopic structure and histochemical structure of the GI submandibular gland. The Avidin-Biotin Complex (ABC) method was used to determine the immunohistochemical reactivity of lectin. After GnRH implantation, the organs were examined and atrophies were observed in organs. In the group in which the implants were removed, it was determined that there was no atrophy; organ structures and microscopic examination were similar to the control group. At the end of the study, submandibular gland was fixed in $10 \%$ buffered formaldehyde. In three groups, PAS and AB histochemical staining revealed similar reactions. Immunohistochemically, lectin activity was found to react positively.

KEY WORDS: Submandibular gland; GnRH; Histochemistry; Lectin; Rat.

\section{INTRODUCTION}

Salivary glands are associated with exocrine tubuloalveolar glands characterized by a cluster of multiple secretory units (Özer, 2016). These units consist of acini where secretions are produced and a duct system that regulates electrolytes in the water concentration, which carries the secretion into the oral cavity. The secretions of the glands are poured into the oral cavity through a number of drainage ducts (Suzuki et al., 2003). Major salivary glands include submandibular and parotid glands (Dursun, 1999; International Committee on Veterinary Gross Anatomical Nomenclature, 2012).

Salivary glands are classified as serous, mucous, and serous-mucous by their structural densities (Suzuki et al.). The salivary glands drain saliva into the oral cavity through drainage channels. These channels are known in the rat as pars initialis, granuler duct, pars secretory, pars excretory, duct excretory, and salivar pouch (Sato \& Miyoshi, 1998). Submandibular gland is almond-shaped in rats and is separated from ligaments by a thin membrane (Sbarbati et al., 1994). The submandibular gland is a serous-type salivary gland (Pinkstaff, 1980).
Gonadotropin releasing hormone $(\mathrm{GnRH})$ is a decapeptide that is secreted and originally isolated from the hypothalamus (Kakar et al., 1992). GnRH combines high affinity $\mathrm{GnRH}$ receptors in the adenohypophysis and stimulates the synthesis and secretion of gonadotropins involved in the regulation of the mammalian reproductive process (Kakar et al.; Perrin et al., 1993). This hormone has high affinity receptors, such as ovary, testis, placenta, adrenal, breast, and prostate, besides the adenohypophysis (Jennes et al., 1988; Perrin et al.). Apart from pituitary tissue, GnRH may also affect cell function and secretion of hormones.

Lectins are glycoproteins that are localized in tissues or glycoproteins that are not immunogenic, linked on at least two sites to carbohydrate chains in glycolipids. Lectins are strong glycoproteins because of their binding properties to specific carbohydrates (Iwase et al., 1981) and purification of enzymes (Dulaney, 1978), isolation of glycoproteins and polysaccharides (Fujita-Yamaguchi et al., 1983), and cancer investigations (Dennis, 1985; Gabius, 1990). In some studies, (Gastman et al., 2004), it has been reported that lectins increase cell numbers and activity by stimulating immune

\footnotetext{
${ }^{1}$ Departments of Histology and Embryology, Faculty of Veterinary Medicine, University of Cumhuriyet, 58140 Sivas TR-Turkey.

${ }^{2}$ Departments of Anatomy, Faculty of Veterinary Medicine, University of Van Yuzuncu Yil 65080 Van TR-Turkey.

${ }^{3}$ Departments of Histology and Embryology, Faculty of Veterinary Medicine, University of Van Yuzuncu Yil 65080 Van TR-Turkey.
} 
system cells. With this effect, it was thought that lectins could be used in the treatment of cancer (Gabius; Kunze et al., 1997). At the same time, lectins are histochemical probes used to identify the specific terminal ends of the carbohydrate sequences of oligosaccharides (Schulte \& Spicer, 1983). Investigation of lectin histochemistry is the vehicle for determining differences in glycoproteins in salivary glands (Brooks \& Carter, 2001).

Several different types of lectin histochemistry have been identified in salivary glands. Glycoconjugates and peripheral sugars have been identified in ducts and in different cell types in flow channel contents in lectin studies on submandibular and sublingual glands. A few lectin specimens have been identified in normal and pathologic conditions with histochemistry of the salivary gland (Hirshberg et al., 1996).

The purpose of this study is to determine histochemical and immunohistochemical changes in the appearance of submandibular gland with the long-term application of the GnRH analogue deslorelin.

\section{MATERIAL AND METHOD}

Animal Material. As animal material, 18 ( $\mathrm{N}=18)$ Wistar albino male rats were used. Animals were obtained from Yüzüncü Yıl University Experimental Animal Unit. Ethics committee approval for the study was obtained from the YYÜ Experimental Animals and Ethics Committee by decision no. 27552122/313, dated April 11, 2013.

Establishment of the Experiment. The 18 rats were randomly divided into three groups:

Group $1(n=6)$, the control group, comprised animals that were not treated.

Group $2(\mathrm{n}=6)$ rats had deslorelin $(4.7 \mathrm{mg})$, a $\mathrm{GnRH}$ analogue, implanted for 6 months.

Group $3(n=6)$ rats were implanted with deslorelin $(4.7$ $\mathrm{mg}$ ) for 6 months, and after implants were removed the rats were observed without implants for another 6 months.

Histochemical Procedure. The rats were sacrificed under anesthesia following $12 \mathrm{~h}$ light and $12 \mathrm{~h}$ dark periods at 23 ${ }^{\circ} \mathrm{C}$, and tissue samples were taken with great care. Salivary glands were first macroscopically examined. In rats, sublingual and submandibular glands were located in the same capsule. After dissection, the histological sections were examined to determine the presence of mandibular glands was differentiated. They were then fixed in $10 \%$ buffered form for $24 \mathrm{~h}$. After routine histologic follow-up, 5-mmthick sections were taken from the paraffin sections and Mallory's triple staining was applied to examine the general structure. Carbohydrate structures with PAS staining were applied to determine $\mathrm{AB}$ (pH: 2.5) acid mucins (Bancroft \& Cook, 1984).

Immunohistochemical Procedure. The sections of 5-mm thickness taken from the adherent slides were deparafinized and subjected to the ABC immunohistochemical method (Karaca et al., 2010). Sections were incubated for 30 minutes with $3 \%$ hydrogen peroxide prepared in methanol for endogenous peroxidase inactivation. Antigen retrieval was then performed in citrate buffer for 20 minutes in the microwave, followed by 10 minutes in $10 \%$ goat serum to prevent nonspecific binding. Without washing (1:200 dilution), incubation with lectin primer antibody (Abcam, UK) for one night was allowed. The sections were then incubated in biotinylated secondary antibody for 20 minutes and then washed three times with Phosphate Buffered Saline (PBS). After soaking for 20 minutes in streptavidin solution, the sections were again washed three times in PBS. Next, Aminoethylcarbazole (AEC) chromogens were applied for 10 minutes to visualize the antigen-antibody reaction in the sections and stained with hematoxylin for 2-3 minutes for background stained. For negative control, the stained sections were subjected to other steps without dropping the primer antibody. After the dyeing, the preparations were evaluated as those with no reaction $(-)$, weak reaction $(+)$, moderate reaction $(++)$, and strong reaction $(+++)$. Suitable areas of the sections were photographed with Zeiss Axioscope.

\section{RESULTS}

Macroscopic Findings. Dissection of the head and neck region was performed after sacrification of the rats. The mandibular glands was macroscopically examined, and it was observed that the capsular mandible was placed caudally in Group 1 with an ovoid bump. In Groups 2 and 3 it was also found that the bedding layout was similar.

Microscopic appearance of mandibular glands. Groups 2 and 3 were found to have a volumetric and structural atrophy. In Group 3, it was observed that this atrophy remained similar to the control group.

Histological Findings. When the microscopic structure was examined, it was seen that the cloths belonging to each of the three groups consisted of a structurally thin ligature capsule with lobes, and lobes with septations formed by the capsule. Compared to Group 1, in Group 2 corpus glands 
were smaller, and lobes were closer to each other and formed a smaller surface area. The decrease in capsular and interstitial areas was structurally similar to that of Group 1 (Figs. 1 and 3). Pars initialis, pars secretory, and pars excretory tracts were similar to the control group (Figs. 1, 2 and 3).

After implant removal in Group 3, histological appearance was similar to Group 1, which was the control group (Fig. 3), when compared with Group 2. Histochemically, it was determined that all groups were
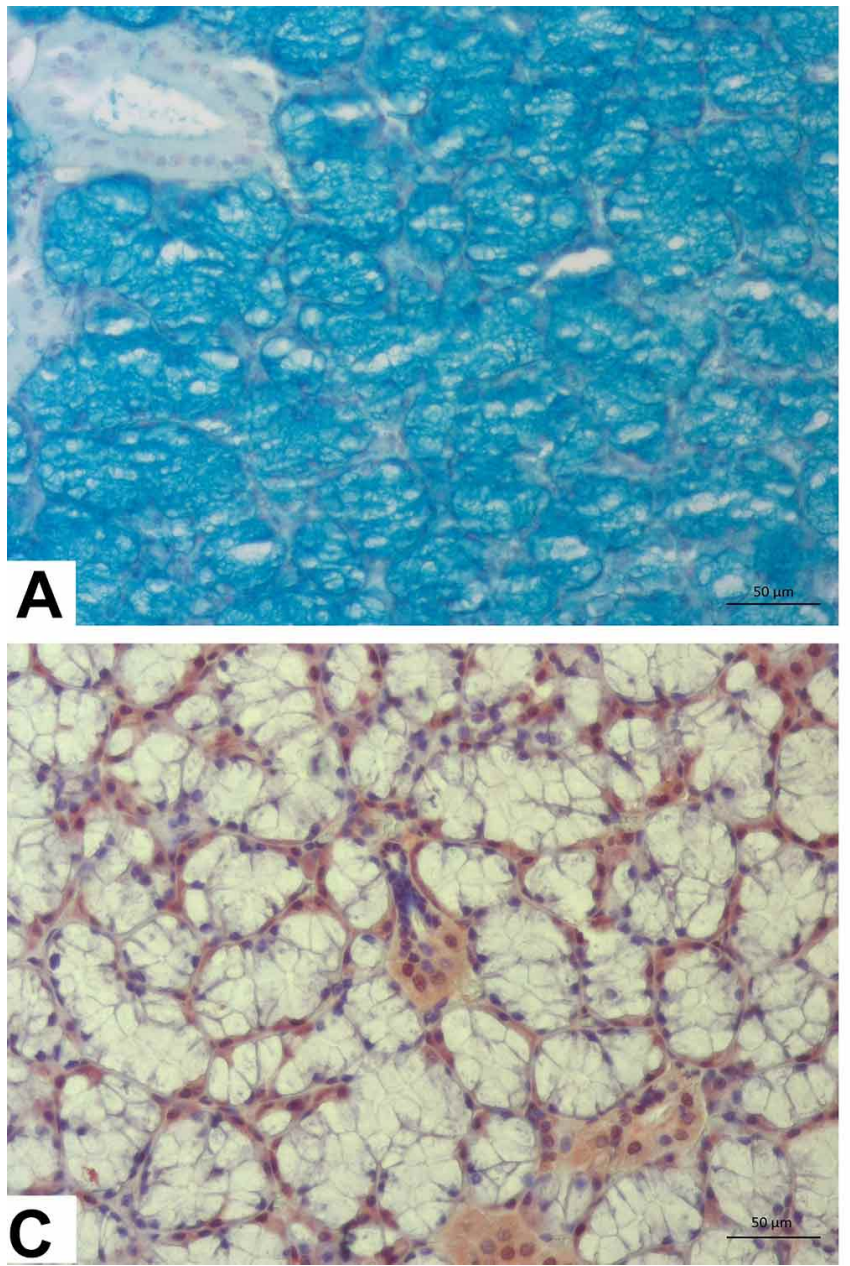

similar in $\mathrm{AB}$ (pH: 2.5 ; +) (Figs. 1A, 2A, 3A), which was similar to PAS (+; Figs. 1B, 2B, 3B). Reaction severity and location of the reaction are shown in Table $\mathrm{I}$. Immunohistochemically, lectin activity was also seen in the half-month of ebner (serous demilune), pars initialis, pars secretory and pars excretory (Figs. 1C,D, 2C,D and 3C,D).

Routine histologic examination of triple-stained sections revealed that the submandibular glands were located in close proximity, separated by thin, fibrous connective tissue.

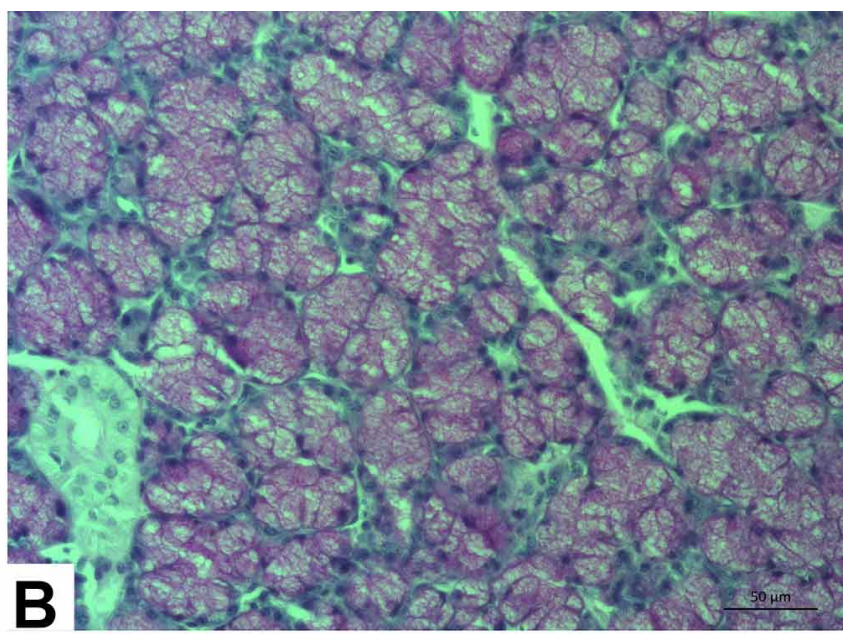

Fig. 1. Control group, A: Alcian-Blue pH2.5, B: PAS, C, D: Lectin immunohistochemically rxn.

Table I. Demonstration of histochemical and immunohistochemical reactions on mandibular gland.

\begin{tabular}{|c|c|c|c|c|c|c|c|c|c|}
\hline & \multicolumn{3}{|c|}{ Group 1} & \multicolumn{3}{|c|}{ Group 2} & \multicolumn{3}{|c|}{ Group 3} \\
\hline & PAS & $\mathrm{AB}$ & Lectin & PAS & $\mathrm{AB}$ & Lectin & PAS & $\mathrm{AB}$ & Lectin \\
\hline Mucous corpus glandula & $(+)$ & $(++)$ & $(-)$ & $(++)$ & $(+)$ & $(-)$ & $(+)$ & $(++)$ & $(-)$ \\
\hline Serous demilune & $(-)$ & $(-)$ & $(+)$ & $(-)$ & $(-)$ & $(+)$ & $(-)$ & $(-)$ & $(+)$ \\
\hline Pars initialis & $(-)$ & $(-)$ & $(+)$ & $(-)$ & $(-)$ & $(+)$ & $(-)$ & $(-)$ & $(+)$ \\
\hline Pars secretory & $(-)$ & $(-)$ & $(++)$ & $(-)$ & $(-)$ & $(+++)$ & $(-)$ & $(-)$ & $(++)$ \\
\hline Pars excretory & $(-)$ & $(-)$ & $(++)$ & $(-)$ & $(-)$ & $(+++)$ & $(-)$ & $(-)$ & $(++)$ \\
\hline
\end{tabular}



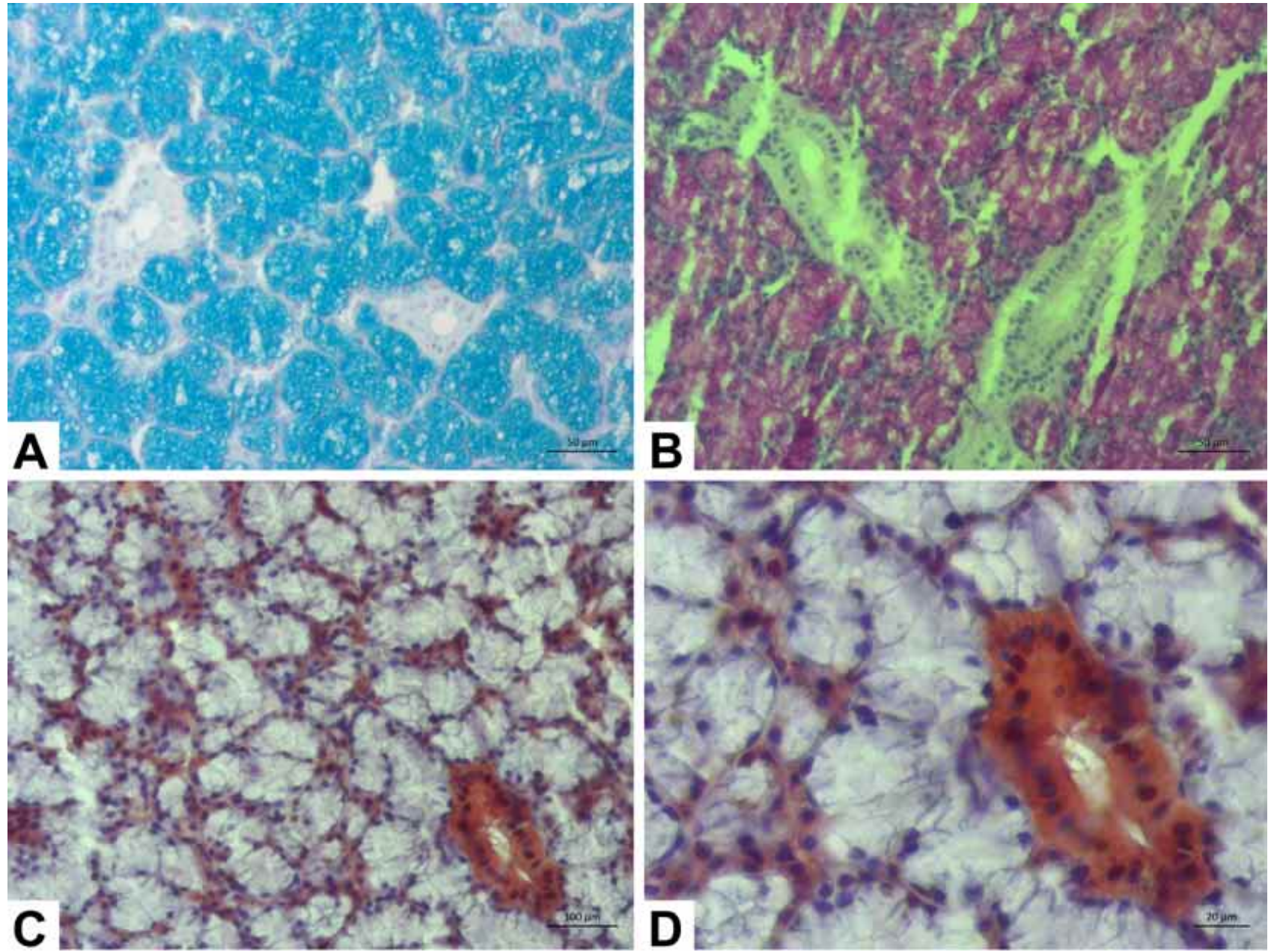

Fig. 2. Group 2, A: Alcian-Blue pH2.5, B: PAS, C, D: Lectin immunohistochemically rxn.

\section{DISCUSSION AND CONCLUSION}

There are many digestive enzymes in saliva secreted by the salivary glands, while gingival sulcus, tonsillary crypts, and epithelial transduction are produced in large quantities. The mandibular gland is a tubuloacinar gland. A fibrous capsule encapsulates this lining. Parenchymal septa are separated by lobes. Many acini are serous, and a few are mucous. Mixed acinous are also found. Mucous asinous are the majority. The mandibular gland releases $5 \%$ of saliva. The gland contains star-like myoepithelial cells that are both serous and fibrous in the cytoplasm of the mix acini. In this study to investigate the effect of a GnRH analogue (deslorelin), it was shown that the anatomical locations of the gland structure, and the general histological structures, in the three experimental groups were similar.

In this study, the histochemical changes in the mixed structure of the mandibular glands after removal of implants for the purpose of monitoring the uremia, and the appearance of retraction after removal, had similar results to those of Zhang et al. (2005) work on the submandibular gland. Sialograms showed a long, horizontal main excretory duct and a pear-shaped gland located inferoposterior to the angle of the mandible. The submandibular glands lay superficial to the suprahyoid and infrahyoid muscle groups and were covered by the inferior portion of the parotid gland. The submandibular glands were characterized by a mixed parenchyma of mucous and serous secretory acini. $\mathrm{AB}$ staining and PAS reactions demonstrated that miniature pig submandibular glands synthesized and secreted acid mucous substances by serous cells and polysaccharide, and neutral mucous substances by mucous cells.

Onwuaso et al. (2015) studied the histological and histochemical properties of submandibular gland in their 



Fig. 3. Group 3, A: Alcian-Blue pH2.5, B: PAS, C, D: Lectin immunohistochemically rxn.

studies on macroscopic salivary glands in giant pouched rats and greater cane rats. In their study, Onwuaso et al., which compared two rats in terms of histological structure, it was seen that animals have mandibular glands of similar structure. Researchers performed PAS and $\mathrm{AB}$ (pH: 2.5) staining to investigate the histochemical structure of the two kinds of rats (Onwuaso et al.). Histologically, serous sections of the serous corpus glands showed strong PAS, and mucous parts showed moderate PAS $(+)$ reaction. In the intralobular ducts and intralobular channels, PAS (-) reacted. In the $\mathrm{AB}$ (pH: 2.5) staining, mucous parts showed strong $\mathrm{AB}(+)$ and serous parts showed $\mathrm{AB}(-)$ reaction. Onwuaso et al. study showed similar results to the PAS and $\mathrm{AB}$ staining results that we conducted in this study. PAS (-) in intratubular ducts was also similar to this study.

In this study, PAS staining was performed in rat mandibular gland, which is one of the histochemical stains used to determine carbohydrate content. It was found that the basal membrane in the subepithelial parts and muscle surroundings reacted at a weak level. It was found that corpus glandula showed a very small positive reaction to PAS staining. It can also be said that a serous-type gland is detected with the detection of serous corpus glandula. Serous cells in reptiles and only mucous cells in amphibians, and mucous cells developed before the serous cells; it has been reported that mucous cells may be pioneer cells in serous glands in phylogenetic terms (Junqueira et al., 1967). The salivary glands are said to be predominant in the developmental stage, and that in gland formation the mucous gland is predominant and has a large number of cells. These findings are similar to the findings of Ikeda \& Aiyama (1997).

As reported by Onwuaso et al., salivary gland morphology and histochemical properties have been reported to vary with factors such as genetics, nutrition, and sex.

In a study conducted by Kelentey et al. (2010), of 
the salivary glands of fluoroquinolone-treated rats, it was reported that the diameter, size, and histological structure of sublingual and submandibular glands changed. Salivary ducts and salivary gland paranchyma in experimental groups, innervation weakened. In our study, the change in the size of the salivary gland was determined to be similar to that of Kelentey et al.

In a study to investigate the effects of laser phototherapy on the salivary gland, Simões et al. (2009), showed that secretagogues such as amylase, catalase, and peroxidase from salivary gland secretions can change even without any contact.

Li et al. (2005) investigated the effects of androgens on both castrated and uncastrated rats and reported that androgen receptor distribution reacts positively with androgen receptor staining in serous corpus and ducts in both groups. In the same study, they reported that epidermal growth factor immunoreactivity was reduced in the salivary glands of the castrated group. Accordingly, the histochemical and histological structure of salivary glands could be altered by reproductive hormones, which is parallel to our findings (Li et al.).

Lectins are glycoproteins. Several different types of lectins have been identified in salivary glands (Iwase et al.). The lectin antibody used in our study has high sensitivity and specificity. Lectin is defined as an anti-idiotypic antibody. A lot of research has been done on the immunohistochemical staining of lectin receptors (Hirshberg et al.). In this study, lectin receptors immunoreactively responded to rat submandibular gland.

The histochemical structure of the salivary gland has been reported to be replaced by hormones (Hirshberg et al.). Immunohistochemically stained and distribution, residential areas are shown in this study. Serous hemisphere, pars initialis, secretory, and excretory lectin immunoreactivity were positive. Accordingly, in the lectin groups 2 and 3, the reaction intensity changed. In Group 2, the lectin reaction was found to change moderately and severely in the presence of less strongly positive areas.

Barnea \& Cho (1982) found that luteinizing hormone (LH) and GnRH administration affects lectin receptor placement. The placement of lectin binders Canavalia ensiformis (Con-A) and Triticum vulgaris (WGA) in the hypothalamic tissue was investigated, and it was determined that there was a change in the amount and location of the lectins after application. In this study, the effects of hormones on the histochemical properties of lectins were in agreement with previous studies supportive.
A study conducted by Zizza \& Desantis (2011) using Atlantic bluefin tuna (Thunnus thynnus) determined that GnRH administration had morphologic and histochemical effects on pyloric epithelium. In the GnRH-treated group, epithelial longer goblet cells and intraepithelial leukocytes were more numerous. Histochemically, the states of ConA, Peanut Agglutinin (PNA), Sambucus nigra agglutinin (SNA), and WGA were examined, and it was observed that GnRH did not react with SNA, PNA, or surface epithelium after lectin application. As a result of their study, it was concluded that the application of GnRH in bluefin tuna pylori affects the lectin histochemistry and the location of the mucins. Similar results were obtained in our study regarding lectin histochemistry and mucin localization of GnRH effect on mandibular glands and histochemical changes of lectin, AB, PAS, and reaction intensity.

According to Yao et al. (2003), immunoreactive substances and their hybridization reveal the signals of GnRH and its receptors in the digestive system, glandular cells, and mucosal epithelial cells. Glandular cells and mucosal epithelial cells are regulated by GnRH and have paracrine and autocrine functions.

Cells localized in the GnRH receptor and mRNA receptor submaxillary gland have been shown by Bing et al. (2003), to be able to modulate the release of Epidermal Growth Factor (EGF) in the GnRH aggregate gl. submaxillary salivary gland depending on the amount of GnRH there. In situ hybridization of submaxillary glands and RT-PCR immunohistochemical techniques are used to investigate whether $\mathrm{GnRH}$ is present in rats (Yao et al.). In this study, it may be said that the effect of GnRH analgesia applied for the control of uremia was similar to that of Bing and his colleagues because it can be seen in the digestive salivary glands, which was not expected.

Matsui et al. (2012) investigated the effect of GnRH agonist use on insulin sensitivity in women with premenopausal leukemia and in healthy women and found that both the endocrine and exocrine portions of the serous pancreas of the salivary gland were affected. In the same study, the amount of C-reactive protein, adhesion molecule1, E selectin, monocyte chemoattractant protein-1, IL-1,6,8, and TNF-a increased while insulin, glucagon, testosterone, estrogen, and steroid hormone binders decreased significantly. Vascular inflammation markers have been identified. In Matsui et al. study, a 6-month waiting period was observed after GnRH administration, and changes detected were observed 6 months later. Changes in the GnRH aggregate that have been made in many widespread organs and changes in the work we do on the salivary gland support findings (Table I). 
Submandibular and sublingual glands have differentiated terminal glycoconjugates in various cell types. Hirshberg et al. conducted studies on the lectin species Con-A, WGA, succinyl WGA (S-WGA), Ricinus communis I (RCA-I), and PNA, and the distributions of European Ulex europaeus (UEA-I) species were investigated histochemically and immunohistochemically. In reactions with PNA serous acinus (+), UEA-I mucous corpus (+), WGA serous acinus $(+)$, Con-A mucous corpus $(+)$, WGA and PNA showed moderate $(+)$ reactivity while RCA-I and Con-A showed intense $(+)$ reaction in flushing channels (Hirshberg et al.). In this study, mannan-binding lectin was used. Serous corpus, pars initialis, pars secretory, and pars excretory ducts were detected in all three groups (+). In addition, it was determined that the severity of reaction seen in pars secretory and excretory is more intense. Histochemical and immunohistochemical changes of lectin were also found in this study, as seen in other similar studies.

In conclusion, rats treated with deslorelin were immunohistochemically investigated, and their lectin activity showed positive reactions in serous acinus, pars initialis, pars secretory, and pars excretory in all three groups as well as increased lectin activity severity in Group 2 . The PAS reaction was detected as (+) in Groups 2 and 3 and $(++)$ in AB staining in Groups 1 and 3.

This study of submandibular gland shows that hormones applied for the control of reproduction may cause changes in the histochemical and histological structures of the salivary glands. When this implant was removed, changes in the tissues were found to be similar to the control group. These findings will contribute to future studies and the literature.

USLU, S.; ÇAKMAK, G. \& YÖRÜK, M. Investigación del efecto de la GnRH (deslorelina) sobre la estructura histoquímica de las glándulas salivales en ratas. Int. J. Morphol., 37(3):10081015, 2019.

RESUMEN: Este estudio se planificó para determinar las alteraciones histoquímicas de la glándula submandibular mediante la implantación de GnRH a largo plazo (deslorelina 4,7 $\mathrm{mg}$ ). Dieciocho ratas Wistar albinas se utilizaron en el estudio. Para determinar la estructura microscópica e histoquímica de la glándula submandibular, se realizó una tinción con azul alcián (AA; pH: 2.5) y ácido peryódico de Schiff (PAS). El método Avidin-Biotin Complex (ABC) se utilizó para determinar la reactividad inmunohistoquímica de la lectina. Después de la implantación de GnRH, se examinaron los órganos y se observó atrofia en ellos. En el grupo en el que se retiraron los implantes, no se observó atrofia. Las estructuras orgánicas y el examen microscópico fueron similares al grupo control. Al final del estudio, la glándula submandibular se fijó en formaldehído tamponado al $10 \%$. En tres grupos, la tinción histoquímica de PAS y AA reveló reacciones simila4res. Inmunohisto-químicamente, se encontró que la actividad de la lectina reaccionó positivamente.

PALABRAS CLAVE: Glándula submandibular; GnRH; Histoquímica; Lectina.

\section{REFERENCES}

Bancroft, J. D. \& Cook, H. C. Manual of histological techniques. New York, Churchill Livingstone, 1984.

Barnea, A. \& Cho, G. Evidence that lectin-binding sites are present on the surface of isolated hypothalamic granules containing luteinizing hormone-releasing hormone. J. Neurosci., 2(11):1644-50, 1982.

Brooks, S. A. \& Carter, T. M. N-acetylgalactosamine, N-acetylglucosamine and sialic acid expression in primary breast cancers. Acta Histochem., 103(1):37-51, 2001

Dennis, J. W. Partial reversion of the metastatic phenotype in a wheat germ agglutinin-resistant mutant of the murine tumor cell line MDAY-D2 selected with Bandeiraea simplicifolia seed lectin. J. Natl. Cancer Inst., 74(5):1111-20, 1985.

Dulaney, J. T. Binding interactions of glycoproteins with lectins. Mol. Cell. Biochem., 21(1):43-63, 1978.

Dursun, N. Veterinary Anatomy II. $5^{\text {th }}$ ed. Ankara, Medisan Press, 1999.

Fujita-Yamaguchi, Y.; Choi, S.; Sakamato, Y. \& Itakura, K. Purification of insulin receptor with full binding activity. J. Biol. Chem., 258(8):50459, 1983.

Gabius, H. J. Influence of type of linkage and spacer on the interaction of beta-galactoside-binding proteins with immobilized affinity ligands. Anal. Biochem., 189(1):91-4, 1990.

Gastman, B.; Wang, K.; Han, J.; Zhu, Z. Y.; Huang, X.; Wang, G. Q.; Rabinowich, H. \& Gorelik, E. A novel apoptotic pathway as defined by lectin cellular initiation. Biochem. Biophys. Res. Commun., 316(1):263-71, 2004.

Hirshberg, A.; Bodner, L.; Naor, H.; Skutelsky, E. \& Dayan, D. Lectin histochemistry of the submandibular and sublingual salivary glands in rats. Histol. Histopathol., 11(4):999-1005, 1996.

Ikeda, R. \& Aiyama, S. Developmental changes in mucous cells of the early postnatal rat parotid gland: an ultrastructural and histochemical study. Arch. Histol. Cytol., 60(2):185-93, 1997.

International Committee on Veterinary Gross Anatomical Nomenclature (ICVGAN). Nomina Anatomica Veterinaria. Hannover, Editorial Commitee, 2012.

Iwase, H.; Kato, Y. \& Hotta, K. Ovalbumin subfractionation and individual difference in ovalbumin microheterogeneity. J. Biol. Chem., 256(11):5638-42, 1981.

Jennes, L.; Dalati, B. \& Conn, P. M. Distribution of gonadrotropin releasing hormone agonist binding sites in the rat central nervous system. Brain Res., 452(1-2):156-64, 1988

Junqueira, L. C.; Fava-De-Moraes, F. \& Toledo, A. M. Sialic acids in vertebrate salivary glands, saliva and pancreas. Arch. Oral Biol., 12(1):151-7, 1967.

Kakar, S. S.; Musgrove, L. C.; Devor, D. C.; Sellers, J. C. \& Neill, J. D. Cloning, sequencing, and expression of human gonadotropin releasing hormone $(\mathrm{GnRH})$ receptor. Biochem. Biophys. Res. Commun., 189(1):289-95, 1992.

Karaca, T.; Yoruk, M.; Yoruk, I. H. \& Uslu, S. Effects of extract of green tea and ginseng on pancreatic beta cells and levels of serum glucose, insulin, cholesterol and triglycerides in rats with experimentally streptozotocin-induced diabetes: a histochemical and immunohistochemical study. J. Anim. Vet. Adv., 9(1):102-7, 2010.

Kelentey, B.; Deak, A.; Zelles, T.; Matesz, K.; Földes, I.; Veress, G. \& 
Bacskai, T. Modification of innervation pattern by fluoroquinolone treatment in the rat salivary glands. Anat. Rec. (Hoboken), 293(2):2719, 2010.

Kunze, E.; Schulz, H.; Ahrens, H. \& Gabius, H. J. Lack of an antitumoral effect of immunomodulatory galactoside-specific mistletoe lectin on $\mathrm{N}$-methyl-N-nitrosourea-induced urinary bladder carcinogenesis in rats. Exp. Toxicol. Pathol., 49(3-4):167-80, 1997.

Li, H. J.; Yao, B.; Liang, W.; Wang, Y. M.; Xu, Q. L. \& Huang, Y. F. Localization and potential function of androgen receptor in rat salivary gland. Asian J. Androl., 7(3):295-301, 2005.

Matsui, S.; Yasui, T.; Tani, A.; Kunimi, K.; Uemura, H.; Yamamoto, S.; Kuwahara, A.; Matsuzaki, T.; Tsuchiya, N.; Yazurihara, M.; et al. Changes in insulin sensitivity during GnRH agonist treatment in premenopausal women with leiomyoma. Clin. Chim. Acta, 413(1112):960-5, 2012.

Onwuaso, I. C.; Neba, C. P. \& Bello, U. M. Comparative histology and histochemistry of the major salivary glands in the giant pouched-rats (Cricetomys gambianus) and greater cane rats (Thryonomys swinderianus). Indian J. Anim. Res., 49(9):451-60, 2015.

Özer, A. Veterinary Specific Histology. Bursa, Dora Press, 2016.

Perrin, M. H.; Bilezikjian, L. M.; Hoeger, C.; Donaldson, C. J.; Rivier, J.; Haas, Y. \& Vale, W.W. Molecular and functional characterization of $\mathrm{GnRH}$ receptors cloned from rat pituitary and a mouse pituitary tumor cell line. Biochem. Biophys. Res. Commun., 191(3):1139-44, 1993.

Pinkstaff, C. A. The cytology of salivary glands. Int. Rev. Cytol., 63:141$261,1980$.

Sato, A. \& Miyoshi, S. Topographical distribution of cells in the rat submandibular gland duct system with special reference to dark cells and tuft cells. Anat. Rec., 252(2):159-64, 1998.

Sbarbati, A.; Baldassarri, A.; Leclercq, F.; Merigo, F.; Antonakis, K. \& Boicelli, A. Magnetic resonance imaging of the submandibularsublingual complex. Acta Anat. (Basel), 149(1):63-9, 1994.

Schulte, B. A. \& Spicer, S. S. Light microscopic histochemical detection of terminal galactose and $\mathrm{N}$-acetylgalactosamine residues in rodent complex carbohydrates using a galactose oxidase--Schiff sequence and peanut lectin--horseradish peroxidase conjugate. J. Histochem. Cytochem., 31(1):19-24, 1983.

Simões, A.; Siqueira, W. L.; Lamers, M. L.; Santos, M. F.; Eduardo, C. de P. \& Nicolau, J. Laser phototherapy effect on protein metabolism parameters of rat salivary glands. Lasers Med. Sci., 24(2):202-8, 2009.

Suzuki, S.; Mifune, H.; Kamimura, R.; Yabuki, A.; Obara, T.; Matsumoto, M. \& Tsuchiya, K. Fine structure of the parotid and mandibular glands of the cotton rat (Sigmodon hispidus). Exp. Anim., 52(5):441-4, 2003.

Yao, B.; Huang, W.; Huang, Y.; Chui, Y.; Wang, Y.; Li, H.; Pu, R.; Wan, L. \& Zhang, R. A study on the localization and distribution of GnRH and its receptor in rat submaxillary glands by immunohistochemical, in situ hybridization and RT-PCR. Life Sci., 72(25):2895-904, 2003.

Zhang, X.; Li, J.; Liu, X. Y.; Sun, Y. L.; Zhang, C. M. \& Wang, S. L. Morphological characteristics of submandibular glands of miniature pig. Chin. Med. J. (Engl.), 118(16):1368-73, 2005.

Zizza, S. \& Desantis, S. Morphology and lectin-binding sites of pyloric caeca epithelium in normal and GnRH-treated Atlantic bluefin tuna (Thunnus thynnus) Linnaeus 1758. Microsc. Res. Tech., 74(9):863-73, 2011.

\author{
Corresponding author: \\ Sema Uslu \\ Departments of Histology and Embryology \\ Faculty of Veterinary Medicine \\ University of Cumhuriyet \\ 58140 Sivas \\ TURKEY
}

ORCID No: https://orcid.org/0000-0002-2239-7841

E-mail: semauslu43@hotmail.com

Received: 14-01-2019

Accepted: 12-03-2019 